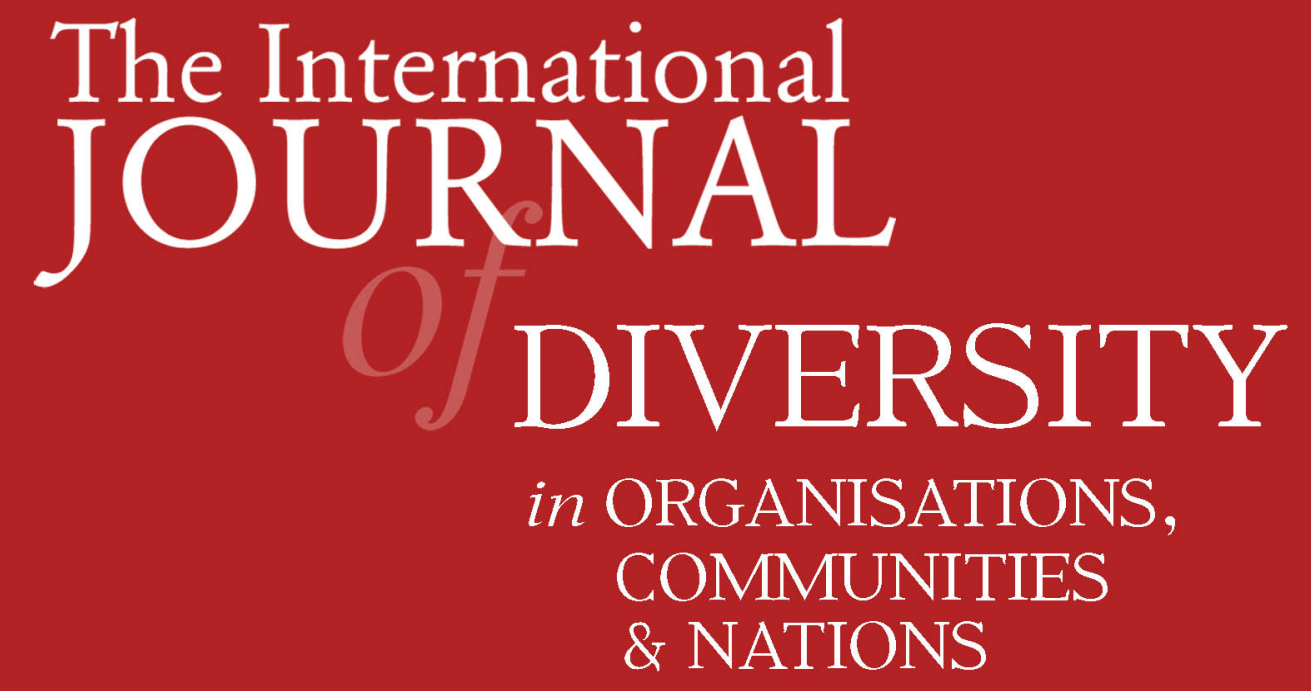

Women and Change in Singapore

Shin Koon Tan Xiaoli Jiang

VOLUME 5, NUMBER 2 
INTERNATIONAL JOURNAL OF DIVERSITY IN ORGANISATIONS, COMMUNITIES AND NATIONS http://www.Diversity-Journal.com

First published in 2005/2006 in Melbourne, Australia by Common Ground Publishing Pty Ltd www.CommonGroundPublishing.com.

(C) 2005/2006 (this paper), the author(s)

(C) 2005/2006 (selection and editorial matter) Common Ground

All rights reserved. Apart from fair use for the purposes of study, research, criticism or review as permitted under the Copyright Act (Australia), no part of this work may be reproduced without written permission from the publisher. For permissions and other inquiries, please contact <cg-support@commongroundpublishing.com>.

ISSN: 1447-9532 (print), 1447-9583 (online)

Publisher Site: http://www.Diversity-Journal.com

The INTERNATIONAL JOURNAL OF DIVERSITY IN ORGANISATIONS, COMMUNITIES AND NATIONS is a peer refereed journal. Full papers submitted for publication are refereed by Associate Editors through anonymous referee processes.

Typeset in Common Ground Markup Language using CGCreator multichannel typesetting system http://www.CommonGroundSoftware.com. 


\title{
Women and Change in Singapore
}

\author{
Shin Koon Tan, University of Ballarat, Australia \\ Xiaoli Jiang, University of Ballarat, Australia
}

\begin{abstract}
It would appear that as Singapore entered the 21st century there have been marked improvements in its women's education attainment, labour force participation and related remuneration. Singaporean women are financially much more independent and are politically and socially more influential. Singaporean families are becoming smaller; women commit to marriage and give birth to their first child much later than previous generations. These changes have raised concerns about sustainability of the future Singaporean labour force for economic development and support for an aging population.
\end{abstract}

Keywords: Singaporean Women, Social, Economic and Political Changes

\section{Introduction}

$\mathrm{S}$ INGAPORE, A SMALL and land-scarce nation with little natural resources, has created rapid economic and social progress over the last 40 years. From a fishing village to independence in August 1965, Singapore had received migrants from different parts of the world and experienced various unpleasant events, including the Second World War.

Today Singapore is widely recognized as an unexpected success story in economic development and is viewed as a newly industrialized country in Asia. During the 1995 Association of Southeast Asia Nations (ASEAN) Summits Conference, the World bank referred to Singapore as one of the "Asian miracle economies" (Association of Southeast Asia Nations, 1995). Recently, Singapore has promoted itself as a model for other Asian countries due to its high growth economy and stable society. The government claimed their approaches to economic development were significantly different from that of Western developed countries as most Singaporeans have a different traditional value system. This is most reflected in hard work and family values. The government also established the Singapore 21 Facilitation Committee to develop new strategies for Singaporeans in the new millennium. One of the five principles adopted is "Every Singaporean Matters" (Singapore 21 Facilitation Committee, 1999). This principle aimed to ensure that every Singaporean played a part in the country's future development and progress. Today women in Singapore play an important role in the development of the country. The current generation of Singaporean women has achieved a much higher level of education and better career prospects. As a consequence, Singaporean women have gained greater financial independence compared to their previous generations.

According to the Singapore Ministry of Statistics Population Census Report in 1998, the female population was larger than the male population prior to the report. Most of the adult women were housewives. They primarily stayed at home and helped out with household chores (Singapore Ministry of Statistics, 1998). This phenomenon had much to do with Chinese culture and traditions. Approximately $76.8 \%$ of the population in Singapore are ethnic Chinese (The Central Intelligence Agency, 2004). For centuries, the status of females in Chinese families has been traditionally low due partly to lack of education and work opportunities. Most Chinese migrants who came to Singapore in the early 1930 - 40s were from Mainland China. These immigrants were usually more conservative and deeply influenced by the teachings of Confucianism and other associated social traditions.

However, in recent years, government legislation has been put in place to ensure equal opportunities for both men and women in all areas. This effort has provided a foundation for Singapore women to achieve unprecedented social progress in recent years. According to the Human Development Report by the United Nations Development Programme , the Singapore gender empowerment measure (GEM) ranked $20^{\text {th }}$ among 144 countries surveyed. Singaporean women have taken an active part in both economic and political life. Singapore also ranked $9^{\text {th }}$ among the 140 countries in the Girls' Investment Index in the Save the Children's 2001 Report (cited in Singapore Ministry of Community Development, 2003a). This index consists of 12 categories measuring the quality of women's lives, which includes education and health care. Further, Singapore women held $16 \%$ of the national parliamentary seats, approx-

INTERNATIONAL JOURNAL OF DIVERSITY IN ORGANISATIONS, COMMUNITIES AND NATIONS, VOLUME 5, NUMBER 2 , 2005/2006

http://www.Diversity-Journal.com, ISSN 1447-9532 (print), 1447-9583 (online)

(c) Common Ground, Shin Koon Tan, Xiaoli Jiang, All Rights Reserved, Permissions: cg-support@commongroundpublishing.com 

VOLUME 5

imately $43 \%$ of women made up the labour force in both professional and technical workers, and $26 \%$ of administrators and managers were women (United Nations Development Programme, 2004). It is apparent there have been many changes in Singaporean women's lives. This paper discusses the progress of Singaporean women in relation to education, economic status, changes within families and other issues facing aging Singaporean women.

\section{Progress in Women's Education}

In order to advance the social status and wellbeing of Singaporean women, a key government strategy was the provision of access to education. The government made the six years of primary school education mandatory for all Singaporeans. This substantially improved women's literacy rate, from 85.8\% in 1995 to $90.6 \%$ in 2002 . There was also a gradual increase in female admissions to polytechnics ${ }^{1}$ and universities. Female tertiary intake increased from $42.1 \%$ in 1990 to $52.5 \%$ in 2002 . This figure was $1.5 \%$ higher than that of the European Union countries (Singapore Department of Statistics, 2003). As a consequence, the number of female undergraduates has increased almost four times and female enrolment in polytechnics rose by ten times comparing to a few decades ago. In an assessment by the Singapore Department of Statistics (2003), it recognised that the changes are largely a result of the establishment of Temasek Polytechnic in 1990 and Nanyang Polytechnic in 1992. At that time, these two newly established polytechnics offered new courses such as publishing and information technology, graphic and product designing, library studies and health sciences. This resulted in a diversification of courses beyond arts and business related courses in tertiary institutions.

There has also been increased female enrolment in sciences and engineering in polytechnics $(11.2 \%)$ and universities (5.3\%) (The Singapore Department of Statistics, 1998). In 1997, 25\% of first year engineering students were female. The ratio grew to $33 \%$ in 2002. As a result, there has been increased numbers of women taking up sciences and engineering related careers (Singapore Ministry of Education, 2002).

\section{Changes in Economic Status}

Improved education attainment in Singaporean women has led to increased female participation in the Singapore labour force. The Singapore Ministry of Community Development (2003b) reported that in 2002 the female labour force participation rate was
$53.4 \%$. A similar participation rate was observed in 2001. These participation rates are significantly higher than that of 1992. A Labour Force Report in Singapore also stated that "The proportion of women in professional, administrative, technical and managerial positions also continued to improve, from $31.3 \%$ in 1992 to $37.3 \%$ in 2001 and further to $37.6 \%$ in 2002" (Singapore Ministry of Manpower, 2002, p. 6). Further, there are significant numbers of female principals in schools and colleges. According to the Singapore Ministry of Education (2002), 70\% of primary school and $58 \%$ of secondary school principals were female, and a further $67 \%$ of junior college principal positions were held by women.

The Singapore government also recognizes the importance of equality in remuneration between men and women in the labour market. In November 2002, A Tripartite Declaration on Equal Remuneration for Men and Women Performing Work of Equal Value was signed among the three key partners ${ }^{2}$ in employment. This declaration is to establish a commitment to the principle of equal remuneration for men and women performing work of equal value. In the following month, a Code of Responsible Employment Practices was jointly issued by the Singapore Business Federation, the Singapore National Employers Federation and the National Trades Union Congress (NTUC). This code is to ensure that the employers promote and observe responsible employment practices in their workplaces regardless of race, age, gender, marital status, disability or other factors that have no relevance to the job requirements. (Singapore Ministry of Manpower, 2003a) ${ }^{2}$

Better education and equality in remuneration have seen improved income levels for Singaporean women. Based on data provided by the Singapore Ministry of Manpower (2003a), the average monthly earnings of females were $\$ 2,256$ in 1998 and this average increased to $\$ 2,617$ in 2002 , an average increase of $3.8 \%$ per annum. In terms of income disparity between male and female workers, the younger female professionals and managers in the age group of 25 to 29 are actually earning $2.0 \%$ to $9.5 \%$ more than their male counterparts (Singapore Ministry of Manpower, 2002). The wage gap between male and female employees has narrowed from 16\% in 1992 to $8.3 \%$ in 2002 for professionals and from $39 \%$ to $24.6 \%$ for production crafts-persons (Singapore Ministry of Community Development, 2003).

Improved education and equal opportunities in employment have resulted in women occupying many important leadership positions such as members of parliament, entrepreneurs, judges, Permanent

\footnotetext{
${ }^{1}$ Polytechnics are considered as tertiary technical institutions. They are equivalent to the Technical and Further Education (TAFE) colleges in Australia. The students in Polytechnics will then graduate with a Diploma.

${ }^{2}$ The three key partners in employment are: The National Trade Union Congress (NTUC), the Singapore National Employers Federation, and the Ministry of Manpower (MoM).
} 
Secretaries in the civil service, diplomats, Commanders in military units, trade union leaders and senior managers.

In Singapore there is an International Management Action Award (IMAA), an annual award jointly administered by the Chartered Management Institute, Singapore and the Standards, Productivity and Innovation Board (SPRING Singapore). This award recognises senior executives who have demonstrated an exceptional ability in taking management actions to achieve sustainable, tangible results for an organisation, society or the nation. It is open to senior executives in business, the public sector, arts, social and community services (Singapore Ministry of Manpower, 2003b). In 2003, amongst the five winners, three were women. It has been suggested by Mr. Lee Suan Hiang, the Chief Executive of SPRING Singapore at the time, that those female winners not only assisted to drive both their own organisations and the economy to new heights, but also proved a role model to others in Singapore society.

The Singapore Civil Service recruitment is open and transparent. The promotion of employees is based on merit. In March 2003, the Singapore Ministry of Community Development (2003b) reported women occupied $56 \%$ of the civil service positions and $62 \%$ of those in the higher ranks of Division I and above. Women also held various positions of leadership in Ministries, Departments and Statutory Boards of the Singapore government. Currently, there are two female Permanent Secretaries and nine female Deputy Secretaries in the Civil Service and $16.0 \%$ of the parliament seats are held by women. This resulted in Singapore being ranked $20^{\text {th }}$ in the world from the 144 countries surveyed. Further, in the Singaporean judiciary system, $45 \%$ of judges in the Subordinate Court and $23 \%$ of the judges in the Supreme Court were women (Singapore Ministry of Community Development, 2003b).

\section{Changes within Families}

With better education and career opportunities for Singaporean women, household duties have become an issue. Many husbands are also under pressure from work. It has been reported that due to lack of supervision from working mothers, some children went astray and neglected their schoolwork leading to failures in school. Their parents are frequently called up by the headmaster of the school. As a consequence, family disharmony, including quarrels and fights, often occur. The wives often face the dilemma of sacrificing their jobs or having a very stressful life while juggling responsibilities both at work and home. Therefore, the demand for foreign domestic workers from the Philippines, Sri Lanka,
Thailand, Bangladesh and India are on the rise. (Singapore Ministry of Manpower, 2004)

In August 2004 the Singapore government reduced the foreign domestic maid's tax levy to assist the need for foreign domestic workers (Singapore Ministry of Manpower, 2004). The intent was to encourage women to remain in the workforce. The advantages of having dual income households are apparent. A second income from a wife's participation in the labour force would enable much higher disposable dollars for leisure and recreation. It would appear the quality of life of the wives have also been improved due largely to their financial independence. Relief from the household chores also means more time to spend with their husbands and children. However, several negative perspectives have emerged from this trend in Singaporean families. Some wives have concerns about the professional conduct of their domestic maids and engage in emotional and mental struggle of maternal guilt that they have to leave their children to be cared for by someone else. Sometimes having another female in the household may pose a threat to the wife. Employing a domestic maid has created stressful situations in some households in Singapore (Tan \& Jiang, 2004). In addition, children who grow up in a house that everything is taken care of by a maid tend to develop a "maid dependency syndrome". This can result in a lack of independence and confidence in some children. Critics have raised doubts regarding this practice of raising children. They have warned of the potential negative impacts this practice may have on the future leadership of Singapore and the entrepreneurial spirit in Singaporean youth (Singapore Ministry of Community Development, 2003b).

The active participation of women in the Singapore labour force and their education attainment has also been associated with a falling fertility rate. It has been reported that Singapore's birth rate fell to an all-time low of 1.26 per woman in 2003 , well below the replacement rate - 2.1 per woman (Lee, 2004). Singapore is one of the many developed countries facing this problem. The continued low fertility rate in Singapore is a threat to sustainable economic growth. It is likely to result in constant labour shortages in meeting manpower demands in the near further (Tee, 2004).

A delay in marriage age by many Singaporean women has contributed to the low fertility rate. These women normally have attained a higher level of education and intend to contribute their knowledge and skills to the workforce. It has even been considered as a waste of their time in higher education if they rush into marriage without knowing their own market values. (Singapore Ministry of Community Development, 2003b). The tradition Singaporean value - every adult should get married - has been 
challenged. Singapore parents also believe that their adult children should not rush into marriage until they are financially established. In addition, the delay in marriage has increased the numbers of single women; many may well remain single for life. Most Singaporean women who have a high level of labour force participation are financially independent. This reduces their reliance on financial support within a marriage. In addition, in a fast-paced, urbanized city like Singapore, a notable lack of opportunities for potential marriage partners to meet and interact is also a contributing factor to an increased number of single women (Singapore Ministry of Community Development, 2003).

Delayed marriages among Singaporean women have also resulted in delays to childbearing. The Singapore Department of Statistics Report in 2002 showed that on average Singapore mothers who gave birth to their first child in 2000 were 28 years old, three years older than those first-time mothers in 1980 (Singapore Department of Statistics, 2002). The postponements of marriage and childbearing have contributed to a lower birth rate. As a result, family size has become smaller. Singaporeans' perceptions of the desirable family size have also changed. The number of children preferred in a family has declined over the years. In 1997, the desired family size, on average, was 2.6 children whereas 3.7 children was the ideal figure in 1973. This declined rate was across the board for all ages (Singapore Department of Statistics, 2002). Many young couples prefer to spend more time in their own "world of two" in the first few years of their marriage and do not wish to have their first child too early. They consider that going through the whole childbearing procedure is a new discovery for them but is, nevertheless, a burden. (Tee, 2004)

Prolonged low fertility under the expected replacement level in Singapore has raised similar issues faced by other developed countries. These include imbalances of age structure, an aging population and labour shortage (Lee, 2004). With the existing low fertility rate, shortfall in labour supply for Singapore's growing economy may not be met by Singaporeans, instead by migrants. During the last decade, import of skilled migrants has become an important source in maintaining the growth in the labour force. The migrants have brought their skills and experiences to the Singapore economy (Lee, 2004). The integration between the locals and skilled migrants has led to Singaporeans being receptive to new ideas and ways of life. This has benefited its economy in a globalising world in many different ways. However, differences in cultural orientation and value system may pose a new challenge to Singaporeans (Lee, 2004).

\section{Some of the Issues Facing the Aging Singaporean Women}

Since 1980 aging is one of the major issues faced by the Singapore government. This is largely attributed to a continuous low mortality rate in Singapore, particularly in their female senior citizens, - below 1\% since 1980 (Singapore Ministry of Health, 2002). The country's birth rate hit an all-time low of 1.26 in 2003 with just 37,600 births, well below the population replacement rate of 2.1 (Tee, 2004). This issue was further raised by the Singapore Prime Minister, Mr. Lee Hsien Loong, in the National Rally in 2004 (Zainol, 2004). According to a report by the Singapore Ministry of Community Development (2004), the life expectancy of Singaporean women has reached 80.6 years. Women, on average, live longer by about 4 years than men. They will eventually form the majority of the aging population in Singapore who are over 75 years.

In order to help families and the elderly remain active in the community and to meet their special needs, the Singapore government has implemented a large number of community-based health and social services. Since September 2001, an Active Seniors Programme has provided a wide range of opportunities for the elders to take up meaningful and fulfilling roles in community activities and share their talents, knowledge and skills with the younger generation. S\$1 million annually has been set aside by the government to co-fund similar innovative ideas or projects (Zainol, 2004). However, many aged women in Singapore are having financial difficulties. They also have lower levels of education and little knowledge regarding their citizenship rights. It has been considered by many of the senior citizens that the financial support provided by the Singapore Social Welfare Department was far from sufficient in supporting their daily living. Many believe that it is a disgrace to approach government for help. They would rather collect recycled materials or work in fast food restaurants, such as the McDonald, than to seek help from the government (Zainol, 2004).

Health issues of Singaporean senior citizens also deserve attention. The past president and current member of the Association of Women for Action and Research, Dr. Kanwaljit Soin, an orthopaedic surgeon, has had grave concern for older women who suffer from osteoporosis and need medication. It would appear that the medication is too expensive for many senior citizens. They do not want to financially burden their children because of the costs of treatment. However, Dr. Soin believes that without medication, many aged women would end up with a fractured hip. In the end, it will cost themselves, their children and society much more (Zainol, 2004). It would appear that the Singapore government needs to face the reality of an aging population and work 
to improve the welfare and medical support of the aged. For many years, these women have been the foundation of their families in raising their children and supporting their husbands in their work. They actively contributed to the development of the Singapore economy and society. In their old age, they should deserve better.

\section{Conclusion}

In recent years the changes in the lives of Singaporean women have been profound. The government has played a leadership role in promoting gender equality. Singaporean women have been provided equal opportunities to education and employment. The Women's Charter, enacted in 1961, safeguards women's rights in matters relating to marriage and divorce which includes matrimonial assets and the maintenance as well as custody of children. It also provides protection for women from domestic violence and sexual offences. These have all significantly improved the socio-economic status of women in Singaporean society. However, the Singapore government is facing the dilemma of a very low fertility rate and the continued need for a labour force to sustain the economy and an aging population. The government also needs to consider how best to support its senior female citizens. It would appear that this population has been disadvantaged due to their relatively weak financial position. Further research regarding the health and wellbeing of aged Singaporean women would assist our understanding of the difficulties and support required for this special group of citizens.

\section{References}

Association of Southeast Asia Nations. (1995). The Fifth ASEAN Summits Report. Bangkok: Association of Southeast Asia Nations.

Lee, R. (2004). Parenthood gets a \$300m boost. Singapore: Singapore Press Holdings.

Mills, S. (1997). Turning Away From Technology. Sierra Club Books.

Singapore Department of Statistics. (1998). Population Census Report. Singapore: Singapore Department of Statistics. Singapore Department of Statistics. (2002). Population Census Report. Singapore: Singapore Department of Statistics. Singapore Department of Statistics. (2002). Report on Wages in Singapore 2002. Singapore Department of Statistics. Singapore Department of Statistics. (2002). Statistics Report. Singapore: Singapore Department of Statistics.

Singapore Department of Statistics. (2003). Statistical Highlights. Singapore: Singapore Department of Statistics.

Singapore 21 Facilitation Committee. (1999). Singapore 21 Report: Chapter 2 Every Singaporean Matters. Singapore: Central National Education Office.

Singapore Ministry of Community Development. (2002). Labour Force Report in Singapore 2002. Singapore: Singapore Ministry of Community Development.

Singapore Ministry of Education. (2002). Singapore Education Statistics Digest 2002. Singapore: Singapore Ministry of Education.

Singapore Ministry of Health. (2002). Singapore Maternal Mortality Rate in 2000. Singapore: Singapore Ministry of Health. Singapore Ministry of Manpower. (2002). Labour Force Report 2002. Singapore: Singapore Ministry of Manpower.

Singapore Ministry of Community Development. (2003a). Country Report: Singapore. The Regional Meeting of National Machineries for Gender Equality in the Asian and Pacific Region. Singapore: Singapore Ministry of Community Development.

Singapore Ministry of Community Development. (2003b). Labour Force Report in Singapore 2002. Singapore: Singapore Ministry of Community Development.

Singapore Ministry of Manpower. (2003a). Singapore Yearbook of Manpower Statistics. Singapore: Singapore Ministry of Manpower.

Singapore Ministry of Manpower. (2003b). Wages in Singapore 2002. Singapore: Singapore Ministry of Manpower.

Singapore Ministry of Manpower. (2004). Foreign Domestic Worker (FDW) Levy Concession. Singapore: Singapore Ministry of Manpower.

Tan, S. K. \& Jiang, X. (2004). Impact on families: Philippine Domestic workers in Singapore. Asia Pacific Societies in Globalisation and Localisation, The $6^{\text {th }}$ Conference of the APSA. Seoul: The Asia-Pacific Sociological Association

Tee, H. C. (2004). Govt foots bill for longer maternity leave. Singapore: Singapore Press Holdings.

The Central Intelligence Agency (CIA). (2004). Singapore, The World Factbook Retrieved June. 18, 2005 from the World Wide Web: http://www.odci.gov/cia/publications/factbook/ United Nations Development Programme. (2004). Human Development Report: Cultural Liberty in Today's Diverse World. New York: United Nations Development Programme

Zainol, V. (2004). No golden years for these women. Singapore: Singapore Press Holdings.

\section{About the Authors}



VOLUME 5

Presented "Impact on Families: Philippine Domestic Workers in Singapore" at 6th APSA Conference: Transmigrant Workers and Civil Society II, in Seoul.

Dr. Xiaoli Jiang

School of Behavioural and Social Sciences and Humanities, University of Ballarat. 
THE INTERNATIONAL JOURNAL OF DIVERSITY IN ORGANISATIONS, COMMUNITIES AND NATIONS

EDITORS

Mary Kalantzis, RMIT University, Australia.

Paul James, RMIT University, Australia

EDITORIAL ADVISORY BOARD

Andrew Jakubowicz, University of Technology, Sydney, Australia.

Jock Collins, University of Technology, Sydney, Australia.

Aihwa Ong, University of California, Berkeley, USA..

Rob Walker, Keele University, UK..

Ha Jingxiong, Central University of Nationalities, Beijing, China.

Ning Wang, Tsinghua University, Beijing, China.

Terry Threadgold, Cardiff University, Wales, UK.

David S. Silverman, Xavier University of Louisiana, New Orleans, USA.

Joe Melcher, Xavier University of Louisiana, New Orleans, USA.

Denise Egéa-Kuehne, Louisiana State University, Baton Rouge, USA.

Geoff Stokes, Deakin University, Melbourne, Australia.

Brendan O'Leary, University of Pennsylvania, USA.

Samuel Aroni, University of California, Los Angeles, USA.

James Early, Smithsonian Institution, Washington, DC, USA.

Peter Sellars, Theatre, Opera and Film Director.

Barry Gills, University of Newcastle, UK.

Walter Mignolo, Duke University, USA.

Ien Ang, University of Western Sydney, Australia.

Michael Shapiro, University of Hawai'i, USA.

Duane Champagne, University of California, Los Angeles, USA.

Peter McLaren, University of California, Los Angeles, USA.

Owens Wiwa, African Environmental and Human Development Agency, Toronto, Canada.

Jackie Huggins, University of Queensland, Australia.

Mililani Trask, Indigenous Expert to the Permanent Forum on Indigenous Issues for the Economic Council of the UN Assembly, Hawai'i, USA.

Armareswar Galla, Australian National University, Canberra, Australia.

Guosheng Y. Chen, RMIT University, Melbourne, Australia.

Peter Phipps, RMIT University, Melbourne, Australia.

Bill Cope, Centre for Workplace Communication and Culture, Australia.

ASSOCIATE EDITORS, 2005

Visit: http://www.Diversity-Journal.com

SCOPE AND CONCERNS

Visit: http://www.Diversity-Journal.com

SUBMISSION GUIDELINES

Visit: http://www.Diversity-Journal.com

INQUIRIES

Email: cg-support@commongroundpublishing.com 